\title{
MATAR O TÉDIO, PASSAR O TEMPO - CRIME E MAL-ESTAR NA TEMPORALIDADE
}

\section{Gabriela Simões Pereira}

Bacharel em Direito pela Universidade Federal do Rio Grande. Mestranda em Letras, área de concentração em História da Literatura, pela mesma universidade. Advogada.

E-mail: gabrielasimoespereira@gmail.com

\section{RESUMO}

Neste ensaio, relaciono a experiência do tempo moderno com o tédio, esse compreendido como um sentimento de mal-estar na temporalidade decorrente da aceleração e da contração do tempo. Para Walter Benjamin, a experiência moderna do tempo possui como metonímia a figura do relógio e caracteriza-se pelo presente perpétuo sem rememoração, pela sucessão homogênea geradora do desaparecimento do sentido da ação. Defendo que tal experiência leva à claustrofobia devido à perda da autonomia, ao extermínio da espontaneidade, à rotinização da existência humana. Com as contribuições da criminologia cultural, busco pensar o crime como um rompante de transgressão da vida reduzida ao fluxo da mercadoria e à velocidade da informação, em que o tédio surge como motivador de momentos ilícitos e de insurreições político-culturais. Também identifico a relação entre tédio e tempo moderno a partir da análise do conto Passeio Noturno I, do escritor brasileiro Rubem Fonseca.

PALAVRAS-CHAVE: Tédio. Crime. Modernidade. Mal-estar. Tempo. 


\section{MATAR O TÉDIO: UMA INTRODUÇÃO}

Niels H., enfermeiro, condenado à prisão perpétua pela morte de dois pacientes 2015, Alemanha. Aplicava injeções que levavam seus pacientes à beira da morte a fim de, logo em seguida, demonstrar sua habilidade em reconduzi-los à vida. À época do julgamento, confessou ter praticado outros homicídios, somando o número de trinta, todos motivados pelo tédio (Correio do Povo, 26 fev. 2015).

Conta Raoul Vaneigem (1967, p. 43, tradução minha): "Um assassino de dezesseis anos declarou recentemente: 'Matei porque estava entediado"”. E acrescenta: "Qualquer um que já sentiu crescer em si a força de sua própria destruição sabe com que cansaço negligente ele poderia vir a matar os organizadores do tédio. Um dia. Por acaso".

Em Paris de 68, um muro trazia esta frase: "Nós não queremos um mundo onde a garantia de não morrer de inanição traga o risco de morrer de tédio" (VENEIGEM, 1967, p. 9, tradução minha). Em outro: "Tédio é contrarrevolucionário" (FERREL, 2010, p. 342). Desde o Uruguai, Eduardo Galeano escreve: "Estamos condenados a morrer de fome, morrer de medo ou a morrer de tédio, isso se uma bala perdida não vier abreviar nossa existência" (GALEANO, 2013, p. 7-8).

Andy Warhol filma, em 1963, Sleep: são cinco horas e vinte minutos, em planosequência, capturando o sono de um amigo do artista. Na ocasião da première do filme, duas pessoas, entre as nove presentes, foram embora antes de contar uma hora de exibição alegando estarem "morrendo de tédio"1.

O pôster para a música Pretty Vacant dos Sex Pistols, desenhado em 1977, por Jamie Reid, traz a imagem de dois ônibus urbanos, lado a lado, o primeiro indicando para "lugar algum" e o segundo para “tédio" (FERREL, 2010, p. 342)

Em 1996, o movimento Reclaim the Streets bloqueou a autoestrada londrina M41 para a realização de um festival da resistência marcado por performances musicais, danças de rua, figuras carnavalescas e uma grande faixa alertando para as consequências do tédio: “A sociedade que suprime todas as aventuras produz a abolição da única aventura possível” FERREL, 2010, p. 342). Os organizadores do festival alegaram querer "sair da rotina", matar o tédio.

1 Mais informações disponíveis em: http://www.warholstars.org/sleep.html; acesso em 14 set. 2016. 
E, por certo, o spleen², de Charles Baudelaire: "É o Tédio - O olhar esquivo à mínima emoção / Com patíbulos sonha, ao cachimbo agarrado. / Tu conheces leitor, o monstro delicado. / - Hipócrita leitor, meu igual, meu irmão!” (BAUDELAIRE, 2012, p. 11).

Esse mapeamento pessoal e propositalmente lacunar tem por objetivo algumas reflexões. Peço que lancemos um olhar sob o tédio e, com isso, possamos entendê-lo não só como um sentimento comum à experiência da vida cotidiana, mas como um princípio organizador da modernidade, uma categoria de entendimento e de imersão do homem no tempo moderno. Pensando a partir de Jeff Ferrel (2010, p. 349) e da criminologia cultural ${ }^{3}$, faço alguns questionamentos: o que o tédio pode dizer sobre os momentos de excitação ilícita, sobre a simbologia, os sentidos e a experiência moderna do crime? O tédio foi/é pedra de toque de políticas de movimentos sociais? Ele pode ser (contra)revolucionário? O tédio produziu/produz dinâmicas de rebelião cultural?

Para o horror dos fiscais de metodologia científica, não me proponho a responder tais perguntas - seria uma tarefa colossal para a qual apenas um ensaio não comportaria, mas anos de pesquisas. Elas me servirão como empenho para especulação. Comprometo-me, sim, a lançar um olhar para a relação entre a experiência moderna do tempo e o sentimento de tédio. Vou começar a fazê-lo a partir de uma pequena história sobre o tédio; em seguida, mostrarei o desdobramento do tédio na ficção de Rubem Fonseca, especialmente no Passeio Noturno I.

\section{ORIGENS DO TÉDIO? A MELANCOLIA E O PAR ACÍDIA E TRISTEZA.}

"Melancolia" é originária da expressão grega melan-cholía que significa bílis negra. Na tradição clássica, está relacionada com a teoria dos humores, a qual entendia a saúde como

\footnotetext{
2 Spleen é um vocábulo de origem inglesa. O francês incorporou-o ao seu léxico no século XVIII para designar o sentimento de tédio.

3 A criminologia cultural surge como uma emergente orientação da sociologia, da criminologia e da justiça criminal. Busca pensar a convergência da cultura e do processo criminal na vida social contemporânea. Pode-se buscar, na década de 1970, na Escola de estudos culturais de Birmighan e na New Criminology britânica, as origens do enfoque da criminologia cultural. Entre os estudiosos que pensam a criminologia cultural destaco: Ferrel, Hedbige, Hayward, Kenneth Thompson, Stuart Hall, Jefferson, Clark, Angela McRobbie, Willis, Stanley Cohen, Jock Young. Suas bases são oriundas dos estudos culturais, das teorias pós-modernas, da sociologia interacionista, do método etnográfico - etnografia do instante - e da análise do discurso. Jeff Ferrell aponta os interesses da criminologia cultural: "criminologia cultural investiga quadros estilizados e dinâmicas vivenciadas por subculturas ilícitas; a criminalização simbólica da cultura popular; e a construção de questões de criminalidade e controle da criminalidade. Além disso, áreas emergentes de pesquisa dentro de criminologia cultural incluem o desenvolvimento dos meios de comunicação e audiências para o crime; os meios de comunicação e cultura de policiamento; as ligações entre o crime, o controle do crime, espaço cultural; e emoções coletivas que moldam o significado do crime" (FERRELL, Jeff. Cultural criminology. In: Annual Review of Sociology. V. 25, 1999, p. 395-396, tradução minha)
} 
o equilíbrio entre os fluidos do corpo. Durante toda a Idade Clássica e grande parte da Idade Média, a teoria dos humores foi o marco para explicar as doenças do corpo e da alma. As primeiras referências à melancolia foram feitas por Hipócrates, nos séculos V e IV a.C. Segundo sua doutrina, as doenças decorrem de uma alteração no equilíbrio dos quatro humores do organismo humanos: sangue, fleuma, bílis amarela e bílis negra. A predominância da bílis negra sobre os demais humores causaria a melancolia; o excesso de bílis amarela seria sinal de temperamento colérico, o de sangue geraria o sanguíneo e o de fleuma, o fleumático (SANTIAGO, 2012, p. 75).

Aristóteles, vincula a melancolia ao homem de exceção, ao gênio: que se dedica à filosofia, à ciência do Estado, à poesia ou às artes (ARISTÓTELES, 1998). A bílis negra, devido à sua natureza inconstante, faria do melancólico um homem instável e, por isso, com potencial criador/inovador. A excepcionalidade e a excentricidade do melancólico reside no fato de ser ele, ao mesmo tempo, genial e doentio, questionador dos sentidos e significados cultural e socialmente estabelecidos. Ao longo da Idade Média, a teoria dos humores manteve-se como referencial para estudo dos sintomas doentios do corpo e da alma. Apesar da melancolia continuar ligada ao excesso de bílis negra, no medievo, houve a introdução do conceito de "acídia", que assumiu o posto entre um dos oito pecados capitais - em sua origem, os pecados capitais eram oito. Evagrio Pontico, por volta de 375 d.C., elaborou uma lista dos principais vícios da alma humana, entre eles encontrava-se o par acídia e tristeza:

\footnotetext{
O demônio da acídia, também chamado de demônio do meio-dia, é o mais pesado de todos. Ataca o monge a partir da quarta hora e persegue a alma até a oitava. Primeiro, faz o sol mover-se lentamente, como se ele fosse quase imóvel, o dia parece ter quase cinquenta horas. Depois, obriga o monge a manter os olhos fixos nas janelas, a odiar sua cela, a observar o sol para ver se falta muito para a nona hora e a olhar aqui e ali [...]. Inspira-lhe aversão pelo lugar onde mora, por seu modo de vida, pelo trabalho manual e, finalmente, sugere que a caridade desapareceu entre os irmãos e que não há nada para consolá-lo. (PONTICO, 19756, apud SANTIAGO, 2012, p. 83, tradução minha)
}

Avicena enumera os signos da acídia: medo sem causa, a tristeza, a angústia, a irritação e a preferência pela solidão, as palpitações, os ruídos nos ouvidos, as moléstias dos hipocondríacos, a perda de apetite. Nos séculos XII e XIII, o pensamento escolástico enfatizou a dimensão mental da acídia, ligando-a à fadiga, ao fastio, à falta de fervor. A acídia passou a ser entendida não só como padecimento, tristeza, aflição, mas como um vício que levava o homem a cometer outros tantos desvios, tais como a ociosidade espiritual, o abandono dos deveres religiosos, a recusa dos bens do espírito. $\mathrm{Na}$ história dos pecados 
capitais, a acídia é um vício espiritual grave porque implica na negligência do homem em relação à adoração a Deus.

A partir do Renascimento, houve um apagamento da ideia de acídia e sua substituição pelo pecado da preguiça. Associada à ascensão da burguesia e do capitalismo - e do protestantismo, principalmente da ética calvinista que condena o descanso sob a posse (WEBER, 2004) -, a introdução da preguiça no lugar da acídia demonstra uma tentativa de concordância dos valores religiosos com a ordem capitalista centrada no valor do trabalho. A condenação de preguiça como negligência ao labor terminou por contrariar a ideia de acídia, uma vez que esta pressupunha a negligência aos bens espirituais (vício espiritual), enquanto a preguiça seria um pecado carnal - a negação do trabalho braçal.

Significativa para a transição da acídia enquanto pecado medieval para a ideia de preguiça é a gravura "Melancolia I", de Albrecht Dürer, datada de 1514, período do Renascimento Alemão. Em primeiro plano encontra-se uma mulher/anjo alada(o), segurado na mão direita um compasso sobre um livro fechado. Tem seu rosto apoiado na mão esquerda e o cotovelo tocando a sua perna - traz um olhar não triste, mas enraivecido, visando o além. Seu cabelo é desgrenhado, à cintura uma porção de chaves penduradas e uma bolsa. Pelo chão, aos pés da mulher-anjo alado, encontram-se vários objetos como que desordenadamente organizados: pregos, régua, madeira, plaina. Atrás de si, vemos uma balança suspendida, uma ampulheta, um sino e um quadro mágico-numérico. Temos também a presença, à direita da personagem, de um anjo triste, rechonchudo, e um cão enroscado em si mesmo. No plano mais ao fundo da gravura, vemos um arco-íris, possivelmente enquadrando fachos de luz solar. No centro do arco-íris, encontramos uma figura animalizada - uma fusão de cão, dragão, lobo, com rabo em espiral - que carrega pelos céus uma faixa com a anotação "Melancolia I". 


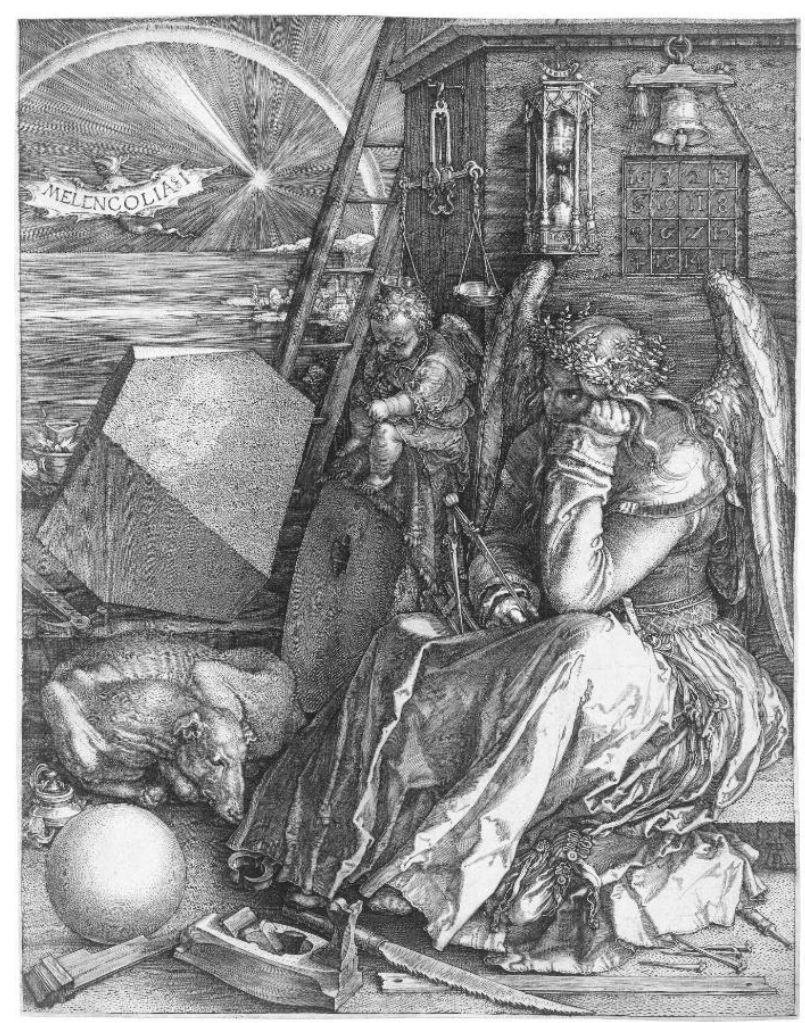

Melancolia I, de Albrecht Dürer (1514) ${ }^{4}$

A obra retrata um oximoro: a melancolia alada. A personagem é, ao mesmo tempo, alada e melancólica; podendo voar, permanece paralisada; triste e enraivecida; cercada pela técnica e por instrumentos de trabalho/construção, mas transparece um asco por qualquer esforço. Os índices da gravura dão a entender que a personagem está em uma construção inacabada ou em ruínas. Aqui me interessam duas reflexões a partir da gravura. A primeira: a personagem, com seu olhar embravecido, fixado no além e cercada por objetos símbolos da matemática, da geometria, da carpintaria - enfim, da técnica e da ciência -, parece ignorar a existência do horizonte, da vila que se forma mais atrás das ruínas da construção, exatamente porque tem seu olhar fixado "na" e "para" a técnica. A segunda: a presença de todos estes objetos símbolos da geometrização do espaço e do conhecimento acerca do mundo. A melancolia aparece, na gravura, como a decadência do que é próprio da experiência e a valorização ao que é próprio da técnica, como o desinteresse pela vida em nome da ciência e do progresso.

\section{TÉDIO E MODERNIDADE}

O tédio... Trabalho bastante. Cumpro o que os moralistas da ação; chamariam o meu dever social. Cumpro esse dever, ou essa sorte, sem

4 Disponível em: http://www.albrecht-durer.org/Melencolia-I.html, acessado em 26 de junho de 2016, às $2 \mathrm{~h} 42 \mathrm{~min}$.

5 Walter Benjamin interpreta esta gravura em sua obra "A origem do drama barroco alemão" (BENJAMIN, 1984 , p. 161 e ss.). 
grande esforço nem notável desinteligência. Mas, umas vezes em pleno trabalho, outras vezes no pleno descanso que, segundo os mesmos moralistas, mereço e me deve ser grato, transborda-se-me a alma de um fel de inércia, e estou cansado, não da obra ou do repouso, mas de mim.

(Fernando Pessoa)

A experiência moderna do tempo é marcada pelos signos da aceleração e da contração. Aceleração relaciona-se com a vida na metrópole, o trânsito veloz das mercadorias, o fluxo de capital e as tecnologias da velocidade - desde a invenção do carro à do trem bala, do telégrafo à Internet. A contração do tempo está imbricada com o ritmo acelerado da vida moderna. O tempo escoa: neste encurtar do tempo, sempre insuficiente, a vida humana projeta-se na falta de tempo. Passamos, ao longo da Modernidade, do tempo extensivo da história para um tempo intensivo, uma instantaneidade sem história (MATOS, 2016).

Walter Benjamin define a experiência moderna do tempo como vazia e homogênea. O símbolo desta temporalidade é relógio, metonímia do tempo mecânico, quantitativo, reduzido ao espaço. Ou então a moda: sua temporalidade é a da superstição do novo, que se finge de novo sabendo-se que se trata da repetição do mesmo, do eterno retorno do passado que nunca tem fim (BENJAMIN, 1994, p. 222-232). Ao contrário do tempo relógio ou do tempo da moda, a revolução é a interrupção da eterna volta e o surgimento da mudança profunda. Ela tem por metonímia a figura do calendário. Benjamin traz o exemplo da Revolução Francesa, em que a consciência da ruptura do eterno retorno se manifestou com a feitura de um novo calendário a partir do dia da proclamação da República, em 1793. O tempo da revolução é o da explosão da continuidade histórica, em que se funda a ruptura do cortejo dos vencedores. Por isso, Benjamin compara o tempo revolucionário com o salto de um tigre: um salto dialético fora do tempo contínuo, tanto rumo ao passado como ao futuro (BENJAMIN, 1994, p. 222-232), porque a revolução é, concomitantemente, a instauração de uma fissura no tempo a partir de um recomeço e, também, uma ligação ao passado por meio da tradição.

Em "Paris, capital do século XIX" (2009), Benjamin quer compreender como "em consequência dessa representação coisificada da civilização, as formas de vida nova e as novas criações de base econômica e técnica, que devemos ao século XIX, entram no universo de uma fantasmagoria" (2009, p. 53). A experiência do tempo na modernidade, o valor de exibição da mercadoria - incluindo o homem enquanto mercadoria exposta -, e a coisificação da vida, tudo isso estava presente nas Exposições universais ou Grandville: "Exposições universais são centro de peregrinação ao fetiche da mercadoria" (BENJAMIN, 2009, p. 35). 
Foram precedidas por exposições nacionais da indústria, cuja primeira ocorreu em 1798, no Campo de Marte, conforme nos diz Benjamin. Tais Grandvilles tinham por objetivo divertir as classes trabalhadoras: "Aí, o operariado tem o primado enquanto freguesia" (BENJAMIN, 2009 , p. 35) e enquanto valor de troca:

\begin{abstract}
As exposições universais transfiguram o valor de troca das mercadorias. Criam uma moldura em que o valor de uso da mercadoria passa para segundo plano. Inauguram uma fantasmagoria a que o homem se entrega para se distrair. A indústria de diversões facilita isso, elevando-o ao nível de mercadoria. O sujeito se entrega às suas manipulações, desfrutando a sua própria alienação e a dos outros.

(...)

As exposições universais constroem o universo das mercadorias. As fantasias de Grandville transferem para o universo o caráter da mercadoria. Elas o modernizam. [...] A moda prescreve o ritual segundo o qual o fetiche mercadoria pretende ser venerado. Grandville estende tal pretensão aos objetos de uso cotidiano e inclusive ao cosmo. Ao leva-los até os seus extremos descobre a sua natureza. Ela consiste na contraposição do orgânico. Percebe no ser vivo os direitos do cadáver. Seu nervo vital é o fetichismo, subjacente ao sex-appeal do inorgânico. $\mathrm{O}$ culto à mercadoria coloca-o a seu serviço. (BENJAMIN, 2009, p. 36).
\end{abstract}

Com estes fragmentos, fica claro que a "fantasmagoria" empregada por Benjamin é um conceito oriundo do "fetichismo da mercadoria", de Karl Marx. Para Benjamin, a fantasmagoria da cultura capitalista alcança o seu desdobramento mais brilhante na Exposição universal de 1867, dando prova do apogeu de Paris enquanto capital do luxo e da moda. As Exposições universais atestam que o projeto capitalista deu certo, isso porque alcançou não só técnicas de produção de mercadorias, mas colonizou a vida, no sentido de ditar as formas modernas de sociabilidade. Já existe, nas Grandvilles do século XIX, uma associação entre lazer e consumo. O tempo não dedicado ao trabalho passou a ser destinado à movimentação do mercado, condenando-se o dolce far niete - a doçura de não fazer nada. Além disso, as Exposições eram os monumentos do capitalismo - como o são os shoppings hoje em dia -, a demonstração arquitetônica do valor do trabalho.

A transmutação dos valores próprios da mercadoria para a vida humana, ou seja, a reificação, já é marca latente nas Exposições. A massificação e a padronização, típicas da produção industrial, passam a ocupar as atmosferas da vida humana. O valor do trabalho assume atributos morais, condenando-se o ócio como defeito moral. A ideologia do trabalho, uma forma secularizada da ética protestante, traduz-se como culto à indústria, ao progresso técnico. Traz consigo a ideia de profissão como dever e a de trabalho produtivo como um fim em si mesmo, transformando a ascese em intramundana: o trabalho dignifica o homem! (WEBER, 2004). Em Auschwitz, "o trabalho liberta". 
Benjamin, novamente no livro da "Passagens", estipula ironicamente a data em que o tédio, epidemia moderna, teve seu início:

\begin{abstract}
O tédio começou nos anos quarenta [1840] a propagar-se como epidemia. Diz-se que Lamartine foi o primeiro a dar expressão a este mal. Teve o seu papel numa pequena historieta, na qual trata do conhecido cômico Deburau. Um ilustre neurologista parisiense foi consultado certo dia por um paciente que lhe apareceu pela primeira vez. O paciente lamentou padecer de uma doença da época: falta de vontade de viver, depressão profunda, tédio. "Mas o senhor não tem nada, - disse-lhe o médico depois de uma consulta cuidadosa - deve apenas relaxar, fazer algo para distrair-se. Vá uma noite dessas assistir Deburau e a vida lhe aparecerá de súbito inteiramente diversa". "Ah! Meu caro senhor, eu sou Deburau" (BENJAMIN, 2009, p. 37).
\end{abstract}

É Baudelaire quem recebe destaque no pensamento de Walter Benjamin sobre a modernidade. Nos ensaios dedicados ao poeta, reunidos na obra "Charles Baudelaire: um lírico no auge do capitalismo" (1994), Benjamin encontra o centro da experiência moderna na relação entre spleen e idéal, as duas primeiras partes d'“As flores do mal". O homem moderno vive um jogo de forças entre a consciência aguda e angustiada da dissolução da experiência - spleen - e a necessidade de rememoração de uma experiência não realizável idéal. A modernidade é o tempo do efêmero ou o tempo da moda, que transcorre tão depressa a ponto de impedir qualquer experiência. A multidão é o retrato do homem moderno em sua uniformidade da indumentária, de comportamento e de gestos (BENJAMIN, 1994, p. 125). O homem na multidão, em alusão feita por Benjamin ao conto homônimo de Edgar Allan de Poe, busca seu refúgio contra o abandono e a solidão e encontra a solidão entre muitos outros homens também isolados. O flâneur é um abandonado na multidão, compartilhando com seus iguais apenas a condição de mercadoria. O homem moderno é aquele para quem a experiência compartilhada se perdeu, restando-lhe apenas a vivência privada e imediata; por isso, sente-se banido do calendário, sem qualquer relação com a história e seus semelhantes:

\footnotetext{
Uma rua, um incêndio, um acidente de trânsito, reúnem pessoas, como tais, livres de determinações de classe. Apresentam-se como aglomerações concretas, mas socialmente permanecem abstratas, ou seja, isoladas em seus interesses privados. Seu modelo são os fregueses que, cada qual em seu interesse provado, se reúnem na feira em torno da "coisa comum". Muitas vezes, essas aglomerações possuem apenas existência estatística. Ocultam aquilo que perfaz sua real monstruosidade, ou seja, a massificação dos indivíduos por meio do acaso de seus interesses privados (BENJAMIN, 1994, p. 35).
}

Se a acídia era concebida como pecado mortal que afligia os monges nos mosteiros, o demônio do meio-dia que atacava entre as quatro e as oito horas do dia, fazendo parecer que o sol se arrastava e que o dia tinha bem mais do que cinquenta horas; e se a melancolia, ou a bílis negra, liga-se a uma sintomatologia do corpo, o tédio ou spleen, ao contrário, não é 
sintoma individual, patologia que acomete este ou aquele indivíduo. Isto porque ele é sintoma de história da modernidade, dos processos de industrialização, da rotinização da vida, da formalização e da instrumentalização da razão, da vacuidade de sentido para a vida e a ação humana, da reificação da vida humana; enfim, da vivência de um tempo vazio de experiência.

\section{4 "PASSEIO NOTURNO I"}

"Passeio noturno I" compõe o livro de contos "Feliz ano novo", de Rubem Fonseca, publicado em 1975. O conto narra uma noite de um empresário, a qual, devido à rotinização da vida do narrador-protagonista, pode simular todas e quaisquer noites. O recurso ficcional de uma narrativa em primeira pessoa, escolhido por Rubem Fonseca nesse conto, anula o distanciamento entre o autor e o personagem. Além disso, é responsável por causar uma proximidade entre o personagem e o leitor ao criar um efeito de real, isso é, a verossimilhança externa: um "como se" a personagem relatasse seu dia-a-dia, em tom de conversa, diretamente ao seu ouvinte-leitor. Ocorre uma ruptura do conhecimento prévio do leitor de que se trata de ficção, convencendo-o, ainda que momentaneamente, da existência concreta dessa voz que lhe fala.

O conto inicia quando o narrador-protagonista, um homem de negócios, chega em casa após um dia exaustivo de trabalho, "carregando a pasta cheia de papéis, relatórios, estudos, pesquisas, propostas, contratos" (FONSECA, 2004, p. 249) ${ }^{6}$. Sua mulher joga paciência na cama e dirige-lhe a palavra sem tirar os olhos do jogo, fingindo preocupação: "você está com um ar cansado". A filha do executivo está num quarto treinando impostação de voz, seu filho em outro, escutando música. O narrador-protagonista o sabe apenas pelos "sons da casa", sem realmente vê-los.

Desejando ficar só, vai à biblioteca e finge estar trabalhando: "o lugar da casa onde gostava de ficar isolado e como sempre não fiz nada. Abri o volume de pesquisas sobre a mesa, não via as letras e números, eu esperava apenas”. À mesa do jantar, a família reúne-se. O empresário repara que seus filhos cresceram e que ele e sua mulher estavam ficando gordos. Em clima de apatia, jantam sem se falar, a não ser: "Meu filho me pediu dinheiro

6 A partir de agora, deixarei entre aspas os fragmentos do conto que citarei; porém, por medida estética e para deixar a leitura mais fluida, não referenciarei a página. Por ser um conto pequeno, creio que minha escolha não será prejudicial para quem quiser buscar a citação no texto original. 
quando estávamos no cafezinho, minha filha me pediu dinheiro na hora do licor. Minha mulher nada pediu, nós tínhamos conta bancária conjunta”.

Até esse momento, o tom do conto é o tédio, ou melhor, a intrínseca relação entre o tédio e o estilo de vida burguês. No conto, o sentimento de tédio aflora nas descrições da rotina apática da família: a esposa que joga paciência, os filhos reclusos em seus quartos, o fato de reunirem-se à mesa de jantar sem conversarem entre si, dirigindo-se a palavra apenas para pedir dinheiro; na rotina exaustiva e burocrática do empresário que carrega "pasta cheia de papéis, relatórios, estudos, pesquisas, propostas, contratos", sua vontade de isolar-se na biblioteca para matar o tempo sem nada fazer - "matar o tempo".

De maneira menos óbvia do que nas descrições da rotina, o estilo de escrita empregado por Rubem Fonseca também transparece o tédio envolvendo a cena familiar. A escolha por frases curtas, em sua maioria descrevendo ações - cheguei em casa, fui à biblioteca, etc. -, elaboradas por um narrador-protagonista com pouca densidade psicológica e que trava raras reflexões sobre seu entorno, dão conta de compor uma atmosfera enfadonha ao redor da vida deste burguês. A concisão da linguagem empregada nos enunciados do protagonista, denota seu cansaço, sua indisposição, seu tédio, como se falar lhe fosse um esforço tamanho para o qual não quer se movimentar. Essa mesma concisão também auxilia na composição de uma imagem estereotipada do homem de negócio em seu modo de viver pragmático. O clima conquistado pela concisão da linguagem e pelas descrições das ações das personagens é o da total incomunicabilidade. A família é escrita como uma reunião de corpos isolados, para os quais a vida privada em comum é uma ausência de espaço compartilhado.

$\mathrm{O}$ conto prossegue com o convite do protagonista à sua esposa para um passeio noturno, de carro, apesar dele já premeditar sua recusa: "Vamos dar uma volta de carro? Convidei. Eu sabia que ela não ia, era hora da novela”. Neste momento, há uma ruptura no conto, a qual pode ser observada tanto pela mudança espaço-temporal quando de ordem comportamental do protagonista. Há uma passagem da rotina diurna, burocrática, regrada, do dever e tediosa deste burguês pai, esposo e homem de negócios, para o espaço-tempo da noite, aquele do desregramento, da diversão, do salto para fora da rotina. Esse passeio do protagonista pela noite mostra-se como procura por alguma experiência antitédio a ser obtida por meio da transgressão.

Para sair de casa, o executivo precisa manobrar os carros de seus filhos os quais bloqueiam a saída de seu veículo. Neste trecho, fica explícita a concisão e o uso pragmático da linguagem como recurso narrativo - aqui, a fim de transparecer a ansiedade do 
personagem: "Tirei os carros dos dois, botei na rua, tirei o meu, botei na rua, coloquei os dois carros novamente na garagem, fechei a porta, essas manobras todas me deixaram levemente irritado". A impaciência pelo esforço do narrador é compensada pela visão de uma parte específica do carro, o para-choque: "ao ver os para-choques salientes do meu carro, o reforço especial duplo de aço cromado, senti o coração bater apressado de euforia"; e complementa: "Enfiei a chave na ignição, era um motor poderoso que gerava a sua força em silêncio, escondido no capô aerodinâmico".

O carro é o objeto responsável pela ruptura da rotina tediosa, burocrática, regrada do empresário; é por meio dele que ocorre a transição para o universo da noite. $\mathrm{O}$ comportamento da personagem sofre uma alteração para seu contrário: do tédio para a euforia, da apatia para o entrosamento. A concisão da linguagem, antes empregada no domínio do cotidiano, agora é deixada de lado na descrição do veículo, para o qual a protagonista não poupa adjetivos. Dos elementos que compõem a narrativa, o narrador envolve-se emotiva e intimamente apenas com a máquina. É por meio de um discurso apaixonado que atribui certa corporeidade humana ao veículo que se intensifica por conta da conotação sexual trazida pela frase, especialmente por causa da escolha do verbo "enfiar": "Enfiei a chave na ignição, era um motor poderoso". Há, aqui, um movimento de humanização da máquina contraposto àquele da primeira parte do conto, de reificação do humano. A reificação é escrita no conto desde a vida do narrador protagonista reduzida ao trabalho, das relações exclusivamente monetárias construídas entre os membros da família, transformando o homem em valor de troca - mercadoria. Por outro lado, a própria mercadoria - o automóvel - é mistificada ao ponto de deixar de ter mero valor de troca: devido às suas características estéticas, assume a forma fantasmagórica ${ }^{7}$.

O processo de reificação do humano está imbricado com o sentimento de tédio; a partir do conceito de reificação e de razão instrumental, tentarei esclarecer que o tédio, na sociedade industrial capitalista, é estrutural e, por isso, precisa ser visto como uma categoria para que se possa compreender o homem moderno. Reificação é um conceito-chave do marxismo, elaborado por Lukács (2003), em seu artigo "A reificação e a consciência do proletariado", e incorporado aos estudos da Escola de Frankfurt. Lukács retomou o conceito de "fetichismo da mercadoria", de Karl Marx, de dimensão estritamente econômica, e remodelou-o a fim de pensar o processo de subjetivação na sociedade capitalista industrial.

7 Na sociedade capitalista, o produto do trabalho é transformado em mercadoria, a qual oculta a lembrança do processo produtivo que a originou. O conceito de "fantasmagoria da mercadoria", cunhado por Benjamin a partir dos conceitos de "fetichismo da mercadoria", de Marx e de reificação, de Lukács, significa a não-identidade entre origem do produto do trabalho e a mercadoria (BENJAMIN, 2009). 
Reificação é o processo em que o valor do humano, das relações sociais - valores abstratos apresenta-se à consciência como valor econômico, ou seja, como mercadorias dotadas de valor de troca. A reificação não atinge apenas aquele humano transformado em insumo industrial, dentro das fábricas, mas é difundida por todas as classes e vida social.

Aproximando-se da ideia de reificação, Horkheimer explica o processo de formalização e instrumentalização da razão. Para Horkheimer, à medida que o conhecimento técnico e o domínio da natureza expandiram-se vertiginosamente em nome do objetivo de progresso, "a autonomia do homem enquanto indivíduo, a sua capacidade de opor resistência ao crescente mecanismo de manipulação de massas, o seu poder de imaginação e seu juízo independente" (HORKHEIMER, 2002, p. 7) foram amortizados. A racionalização da vida obliterou a razão em nome do progresso; entretanto, a ideia de progresso está na iminência de arruinar seu próprio objetivo: a ideia de homem (HORKHEIMER, 2002, p. 8).

A formalização é o processo de modificação dos sentidos atribuídos à razão, pelo qual se renuncia o seu vínculo com os fins objetivos e se altera o seu significado de conservação: antes, ligada à preservação da vida em comunidade, agora, vinculada à ideia de autoconservação e domínio da natureza. A formalização resultou na redução da razão a uma função de instrumento para obtenção de fins particulares e tornou-a imersa na mesma lógica do mercado, refém da concepção de utilidade e mensurada pelo critério de eficiência: as ações são "racionais" porque eficientes, na medida em que cumprem com as expectativas e servem a outro fim social gerador de riqueza.

A razão instrumental impôs às coisas do mundo a vacuidade de significação; estas somente são avaliadas pela sua função e utilidade no processo produtivo. Na mesma linha, a vida humana tornou-se um insumo industrial. $\mathrm{O}$ processo de reificação do homem produz o eu-máquina, menospreza qualquer capacidade especulativa da razão e abomina o ócio. A experiência torna-se patológica, porque é experiência de um tempo sem experiência (MATOS, 2016), esvaziado pelos valores da mercadoria, homogeneizado. O sentimento de exílio, de abandono, de solidão no tempo e no espaço, provocado pela mudança nos fins objetivos - do vínculo comunitário à autoconservação - são sintomas de mal-estar na temporalidade. O tédio decorre deste tempo sem experiência. O tédio é filho do tempo da repetição, do tempo da moda, é o sentimento de que a ação humana está condenada à vacuidade de significação.

Cabe distinguir, no pensamento de Benjamin, erfahrung e erlebnis. Erfahrung referese ao conhecimento obtido através de uma experiência que se acumula, que se prolonga no 
tempo, que é compartilhada; enquanto erlebnis remete à pura vivência do indivíduo privado, isolado, que ocorre de forma imediata. Olgária de Matos elucida o emprego da palavra Erfahrung por Benjamin (MATOS, 2016): etimologicamente, o radical fahr significa viajar; no antigo alemão, fahr é "atravessar uma região, durante uma viagem, por lugares desconhecidos". Em latim: "experiência tem como radical per (experiência): sair de um perímetro, sair da condição do já conhecido, do já vivido, para ampliar vivências, acontecimentos e repercussões desses acontecimentos novos nas nossas vidas”. Do radical per também vem a palavra periculum, perigo: atravessar uma região em que ameaças podem surgir: "E, para esses perigos, há a palavra que se associa a periculum, que é oportunus, originada de portus, que quer dizer saída”. Experiência, etimologicamente, traz a ideia de uma travessia no desconhecido, de uma errância que pode ser perigosa e também - ou por isso mesmo - oportuna (MATOS, 2016).

A transição ocorrida no conto de Rubem Fonseca do dia para a noite, do tédio para a euforia, da casa para a rua, pode ser vista como uma travessia no desconhecido: uma busca por experiência nessa rotina medíocre do protagonista desprovida de perigo e de saída. Após o discurso amoroso para seu veículo, a próxima frase do conto deixa claro esse desejo de errância, de romper o tédio com um salto para fora da rotina "trabalho-casa": "Saí, como sempre sem saber para onde ir". Em seguida, o narrador procura, com dificuldade, uma rua deserta, lugar cujas características são ideais para alguma transgressão; encontra-a e perguntase: "Homem ou mulher? Realmente não fazia grande diferença". O momento do conto é de tensão, pois o leitor desconhece o que o protagonista ensaia experienciar:

\footnotetext{
Então vi a mulher, podia ser ela, ainda que mulher fosse menos emocionante, por ser mais fácil. Ela caminhava apressadamente, carregando um embrulho de papel ordinário, coisas de padaria ou de quitanda, estava de saia e blusa, andava depressa, havia árvores na calçada, de vinte em vinte metros, um interessante problema a exigir uma grande dose de perícia. Apaguei as luzes do carro e acelerei. Ela só percebeu que eu ia para cima dela quando ouviu o som da borracha dos pneus batendo no meio-fio. Peguei a mulher acima dos joelhos, bem no meio das duas pernas, um pouco mais sobre a esquerda, um golpe perfeito, ouvi o barulho do impacto partindo os dois ossões, dei uma guinada rápida para a esquerda, passei como um foguete rente a uma das árvores e deslizei com os pneus cantando, de volta para o asfalto. (FONSECA, 2004, p. 250)
}

A brutalidade do assassinato não é gratuita. No conto, a violência é elevada ao sentido sublime, ao belo. O protagonista encontra no ato um sentido artístico, para o qual age com perícia - peritus: que tem a experiência de, que adquire conhecimento por experiência. $\mathrm{O}$ narrador não apenas deseja matar, mas quer o fazer de forma precisa, premeditando cada traçado: as árvores exigiam "grande dose de perícia", ela apaga as luzes e acelera para acertar 
exatamente "acima dos joelhos, bem no meio das duas pernas, um pouco mais sobre a esquerda". Um golpe perfeito, cuja demonstração do domínio técnico e precisão do traçado iguala o assassino ao pintor. Substituindo os pincéis por seu automóvel, o protagonista "colore de sangue" o muro de uma casa do subúrbio. O sentido da morte é inexistente para o protagonista, em seu lugar há puro jogo, fruição, gozo, demonstração de perícia: "Motor bom, o meu, ia de zero a cem quilômetros em nove segundos"; "Poucas pessoas, no mundo inteiro, igualavam a minha habilidade no uso daquelas máquinas".

O conto termina com o retorno do narrador-protagonista para sua casa, orgulhoso e satisfeito de seu desempenho. A família estava vendo televisão. Sua esposa lhe pergunta se ele está mais calmo após a "voltinha". Ele: "Vou dormir, boa noite para todos, respondi, amanhã vou ter um dia terrível na companhia”. Após a transgressão em busca de adrenalina, retorna ao universo regrado, enfadonho do cotidiano.

Certo que a produção ficcional de Rubem Fonseca é identificada pela marca da violência, "Passeio noturno" é alvo de repulsa por parte de leitores. São comuns análises que enfoquem o caráter sociopata do narrador-protagonista. Alfredo Bosi (1977, p. 17) chamou de brutalista a estética do escritor, não esquecendo de que tal escrita deriva de um contexto pós golpe civil-militar de 64, de crítica à lógica capitalista e à indústria cultural. Marisa Lajolo e Regina Zilberman atribuem à obra de Fonseca uma "estética do soco-no-estômago" (LAJOLO; ZILBERMAN, 1996, p. 55)

No conto é evidente a presença do brutalismo, da violência e da perversidade, mas nada disso me parece ser gratuito. Aliás, o excesso da violência funciona como um choque elétrico s, para o qual é impossível desviar o olhar, esquecer-se. A força da violência, de seu excesso que leva o leitor a julgá-la inconcebível e sentir-se perturbado por sua crueldade, apresenta-se em uma dimensão de crítica ao estado das coisas, de crítica à reificação do humano, à vida condenada à rotinização, à ausência de imprevistos e excitações e, profundamente, à perda da solidariedade e do senso de comunidade. A transgressão da ordem por meio da violência vem a ser uma resposta à violência velada imposta pelo cotidiano; ao fim, é uma ação política, uma possibilidade de redenção desta vida transformada em insumo industrial: o periculum é a oportunidade, a saída: “Afinal, a procura desesperada de vida em meio ao mortificante tédio, a fronteira entre o prazer e a dor, entre o crime e a comodidade, pode ser, de fato, sutil” (FERREL, 2010, p. 349). 


\section{TÉDIO E CRIME}

Os estudos da cultura precisam atentar para o fenômeno do tédio como categoria de leitura do homem moderno e da experiência "no" e "do" tempo. A solidariedade orgânica parece estar arruinada na época em que o individualismo se pôs como lei; se algo nos une, é o sentimento de tédio, de vacuidade de significações para o nosso estilo mortificante de vida. $\mathrm{O}$ tédio pode surgir não só como categoria importante para os estudos da cultura, mas também como uma abertura emotiva e experimental através da qual podemos visualizar as falhas do projeto modernista (FERREL, 2010, p. 349).

Um dos estudos do criminólogo cultural Jeff Ferrell (2010) é direcionado às interrelações em crime, tédio e criminologia. Para ele, os criminólogos devem investigar as circunstâncias do tédio coletivo historicamente estruturadas, isto porque elas moldam "não apenas os momentos de excitação ilícita, mas as políticas dos movimentos sociais e as dinâmicas de rebelião cultural" (FERREL, 2010, p. 349). O tédio precisa ser visto, desde os estudos da criminologia cultural, como conceito, como princípio organizador comum. Talvez assim ele possa nos dizer algo sobre a experiência moderna do crime, seus sentidos e sua simbologia.

Para o criminólogo, o tédio é sintoma de um apanhado de problemas modernos, tais como o extermínio da espontaneidade humana, a rotinização da existência e o enclausuramento da vida humana nos limites das relações de consumo:

\footnotetext{
Racionalização burocrática, eficiência, rotinização, regulação, padronização, realmente nos encontramos em uma paradigmática situação de tédio. De fato, os vários itinerários da modernidade parecem fundir-se claramente num grande mecanismo de tédio. Quando os repetitivos sussurros das fábricas substituem os ritmos do artesanato, o entorpecimento do trabalho alienado esvazia o significado do trabalho cotidiano e esgota a promessa fraudulenta do progresso moderno. Quando a eficiência se transforma em valor organizacional e cultura, proliferam previsibilidades, relatórios estatísticos emergem como medida de valor e o desenvolvimento pessoal e individual torna-se luxo que muitas organizações modernas não podem suportar. Quando a obediência a regras extremas de regulação racionalizada define o sucesso e até mesmo a moralidade, a mesmice se torna uma virtude, a independência do pensamento um problema e os manuais literatura essencial do cânone moderno. (FERREL, 2010, p. 343-344)
}

Os estudos etnográficos da criminologia cultural dizem algo sobre a relação das subculturas com o tédio: a vontade de recuperar um tempo com experiência, de viver situações - às vezes, situações-limites de adrenalina e risco de morte - que sabotam o estilo de vida tedioso ao qual o homem moderno está condenado. O tédio é um namoro com a morte; quando um grupo escala arranha-céus para pichar no local mais alto; quando se pisa no 
acelerador do automóvel o mais fundo possível; quando se atravessa o sinal vermelho sem olhar para os lados; ou pratica-se esportes radicais; tudo é para sentir que se está vivo, que se possui controle, senão sobre sua vida, pelo menos sobre sua morte. Faz-se necessário pensar se alguns crimes cometidos contra a pessoa ou contra o patrimônio seriam ações contra o tédio. Pequenos furtos em supermercados e shoppings centers ou até mesmo um homicídio, como no caso de "Passeio noturno": "tudo isso sugere experiências antitédio precisamente porque recapturam, ainda que momentaneamente, a urgência da experiência humana autônoma (FERREL, 2010, p. 350)

\section{REFERÊNCIAS}

ARISTÓTELES. O homem de gênio e a melancolia: o problema XXX, 1. Rio de Janeiro: Lacerda Editores, 1998.

BAUDELAIRE, Charles. As flores do mal. Tradução de Ivan Junqueira. São Paulo: Nova Fronteira, 2012.

BENJAMIN, Walter. Sobre o conceito de História. In: Magia e técnica, arte e política: ensaios sobre literatura e história da cultura. Obras escolhidas. Vol. 1. São Paulo: Brasiliense, 1994.

Charles Baudelaire: um lírico no auge do capitalismo. Obras escolhidas. V. 3. $3^{\mathrm{a}}$ ed. São Paulo: Editora Brasiliense, 1994.

Passagens. Belo Horizonte: Editora UFMG, 2009.

BOSI, Alfredo. O conto brasileiro contemporâneo. $2^{\text {a }}$ ed. São Paulo: Cultrix, 1977.

Enfermeiro alemão é condenado à prisão perpétua por morte de dois pacientes. Correio do Povo, Porto Alegre, 26 fev. 2015. Disponível em:

<http://www.correiodopovo.com.br/Noticias/549971/Enfermeiro-alemao-e-condenado-aprisao-perpetua-por-morte-de-dois-pacientes>. Acesso em: 14 set. 2016. 
FERRELL, Jeff. Cultural criminology. In: Annual Review of Sociology. V. 25, 1999.

Tédio, crime e criminologia: um convite à criminologia cultura. Revista Brasileira de Ciências Criminais, 2010.

FONSECA, Rubem. Passeio Noturno, Parte I. In: 64 contos de Rubem Fonseca. São Paulo: Cia. das Letras, 2004.

GALEANO, Eduardo. De pernas pro ar: a escola do mundo ao avesso. Porto Alegre: L\&PM, 2013.

HORKHEIMER, Max. O eclipse da razão. São Paulo: Centauro, 2002.

LAJOLO, Marisa; ZILBERMAN, Regina. A formação da leitura no Brasil. São Paulo: Ática, 1996.

LUKÁCS, Georg. A reificação e a consciência do proletariado. In: História e consciência de classe: Estudos sobre a dialética marxista. São Paulo, Martins Fontes, 2003.

MELANCOLIA I, de Albrecht Dürer (1514). Disponível em: <http://www.albrechtdurer.org/Melencolia-I.html>. Acesso em: 26 jun. 2016

PESSOA, Fernando. Livro dos desassossegos. São Paulo: Cia. Das Letras, 2002

SANTIAGO, Manuela Castro. Las metáforas de la melancolia: um acercamiento deste la filosofia, la literatura y las artes plásticas. Tese de doutorado. Universidad de Huelva, 2012.

VANEIGEM, Raoul. Traité de savoir-vivre à l'usage des jeunes générations. Paris: Gallimard, 1967.

WARHOL, Andy. Sleep. Disponível em: <http://www.warholstars.org/sleep.html>. Acesso em 14 set. 2016 . 
WEBER, Max. Ética protestante e espírito do capitalismo. São Paulo: Cia. das Letras, 2004.

\section{TUER L'ENNUI, PASSER LE TEMPS - CRIME ET MALAISE DANS LA} TEMPORALITÉ

\section{RÉSUMÉ}

Dans cet article, je rapporte l'expérience du temps moderne avec l'ennui (cela signifie un sentiment de malaise dans la temporalité résultant de l'accélération et la contraction du temps). Chez Walter Benjamin, l'expérience moderne du temps a comme métonymie la figure de l'horloge et se caractérise par le présent sans souvenir, en générant la succession homogène du temps et la absence du sens de l'action. Je soutiens que cette expérience conduit à la claustrophobie en raison de la perte d'autonomie, l'extermination de la spontanéité, la routinisation de l'existence humaine. Avec les contributions de la criminologie culturelle, je recherche penser le crime comme la transgression de une vie réduit le flux de marchandises et la vitesse de l'information, où l'ennui se présente comme un facteur de motivation. Je fais aussi la relation entre l'ennui et le temps moderne dans le compte "Passeio Noturno I", du écrivain brésilien Rubem Fonseca.

MOTS-CLÉS: L'ennui. Crime. Modernité. Malaise. Temps. 